\title{
Formulasi Sediaan Gel Rektal Ketoprofen dengan Peningkat Kelarutan Tween 80
}

\begin{abstract}
Sulfia Imami $^{\left({ }^{(a)}\right.}$, Lucia Hendriati ${ }^{(a)}$, Teguh Widodo ${ }^{(a)}$
${ }^{(a)}$ Fakultas Farmasi, Universitas Katolik Widya Mandala Surabaya, Surabaya, Indonesia

Ketoprofen merupakan obat antiinflamasi nonsteroid yang sering digunakan sebagai analgesik pasca operasi yang belum bisa menerima pemberian obat secara oral sehingga ketoprofen diformulasikan dalam bentuk sediaan gel rektal agar efek terapeutiknya dapat dicapai dengan cepat akan tetapi ketoprofen memiliki kelarutan yang rendah. Tween 80 merupakan surfaktan yang digunakan untuk meningkatkan kelarutan ketoprofen. Tujuan dari penelitian ini adalah mengetahui pengaruh Tween 80 terhadap mutu fisik dan laju pelepasan gel rektal ketoprofen. Evaluasi mutu fisik terhadap sediaan meliputi uji organoleptis, homogenitas, uji daya sebar, uji viskositas dan uji pH. Uji pelepasan ketoprofen ditetapkan dengan Franz diffusion cell menggunakan membran whatman 0,45 $\mu$ m dan larutan dapar fosfat $\mathrm{pH} 7,4$ sebagai media reseptor. Kadar ketoprofen ditentukan dengan spektrofotometer UV-VIS. Hasil penelitian menunjukkan bahwa profil pelepasan ketoprofen dipengaruhi oleh konsentrasi Tween 80, semakin besar konsentrasi Tween 80 menyebabkan nilai fluks pelepasan semakin besar. Tween 80 dengan konsentrasi $1 \%, 2,5 \%, 5 \%, 7,5 \%$ menghasilkan fluks pelepasan berturut-turut sebesar 111,660; 155,465; 449,648; $644,853 \mu \mathrm{g} / \mathrm{cm}^{2} / \mathrm{jam}^{1 / 2}$. Berdasarkan analisa statistik dengan Anova menunjukkan perbedaan nilai fluks secara signifikan $(p<0,05)$.
\end{abstract}

Kata kunci: Ketoprofen, gel rektal, tween 80 , fluks pelepasan

\section{Formulation of Ketoprofen Rectal Gel with Tween 80 as Solubility Enhancer}

Ketoprofen is a non steroidal anti-inflammatory drugs, often used as a post operative analgesic for the patient which is oral drug delivery, so ketoprofen should be formulated in rectal gel dosage forms that their therapeutic effect can be achieved quickly and has a low solubility. Tween 80 is a surfactant that is used to improve the solubility of ketoprofen. The purposes of this study were to determine the effect of Tween 80 on the release of ketoprofen and the physical quality of rectal gel. Evaluation of physical quality of the preparation includes organoleptic test, homogeneity test, spreadability test, viscosity test and $\mathrm{pH}$ test. The release of ketoprofen determined by Franz diffusion cell using whatman membrane $0.45 \mu \mathrm{m}$ and a solution of $\mathrm{pH} 7.4$ phosphate buffer as receptor media. The amount of ketoprofen pass in through the membrane was determined by UV-VIS spectrophotometer. The results showed that the release profile of ketoprofen was affected by the concentration of Tween 80 , the greater the concentration of Tween 80 the greater the value of flux release. Tween 80 at the concentration $1 \%, 2.5 \%, 5 \%, 7.5 \%$ produce release flux values of $111.660 ; 155.465 ; 449.648 ; 644.853 \mu \mathrm{g} / \mathrm{cm}^{2} /$ hour $^{1 / 2}$. Statistical analysis by Anova of difference release flux values of each formula were significantly different $(p<0.05)$.

Keywords : Ketoprofen, rectal gel, tween 80, release flux.

*Corresponding author: Fakultas Farmasi Universitas Katolik Widya Mandala Surabaya, Jl. Raya Kalisari Selatan No. 1 Surabaya, e-mail: sulfia_imami@yahoo.com 


\section{PENDAHULUAN}

Ketoprofen merupakan senyawa obat antiinflamasi nonsteroid (OAINS) turunan asam fenilalkanoat yang bekerja sebagai antiinflamasi, antipiretik, analgetik, dan secara luas digunakan sebagai antireumatik (Hosny et al., 2013). Berdasarkan daftar obat esensial nasional (DOEN) tahun 2008 ketoprofen supositoria sebagai analgesik non narkotik dengan dosis 100 mg digunakan pada pasien pasca operasi yang belum bisa menerima pemberian obat secara oral dan tidak mengiritasi lambung (Depkes RI, 2008). Pemberian ketoprofen melalui oral memiliki efek samping pada gastrointestinal seperti perdarahan saluran cerna bagian atas, ulkus, obstruksi, dispepsia, dan cara untuk mengatasi kelemahan tersebut ialah dengan memberikan obat melalui rektal. Rektal manusia merupakan salah satu tempat yang dapat digunakan untuk penghantaran obat. Rute rektal merupakan salah satu rute pemberian alternatif untuk obat yang memiliki kelemahan apabila diberikan secara per oral dapat mengiritasi saluran cerna (Allen, 2009).

Ketoprofen merupakan obat yang termasuk dalam kelompok Biopharmaceutical Classification Systems (BCS) class II yang memiliki kelarutan rendah dan permeabilitas tinggi.Kelarutan obat berkaitan dengan proses absorbsi dan bioavailabilitas dalam tubuh yang dapat menentukan efek farmakologi. Kelarutan obat yang rendah juga mempengaruhi laju disolusi dan kadar obat dalam tubuh (Rencber, Karavana, and Ozyazici, 2009). Salah satu upaya dalam meningkatkan kelarutan obat yaitu dengan menambahkan surfaktan dalam proses formulasi (Yadav, Kondawar, and Varne, 2013). Tween 80 merupakan surfaktan nonionik yang dapat menurunkan tegangan antar muka obat dengan medium sehingga dapat meningkatkan kelarutan. Bentuk sediaan yang dapat diberikan melalui rektal yaitu gel. Gel memiliki keuntungan dibandingkan bentuk suppositoria yaitu karena tidak membutuhkan waktu untuk meleleh pada suhu tubuh $\left(37^{\circ} \mathrm{C}\right)$ serta memungkinkan polimer gel dapat menempel dan menyebar dalam mukosa rektum bercampur dengan cairan rektum, memiliki pelepasan obat yang baik sehingga proses absorbsi lebih cepat terjadi, dan mula kerja obat lebih cepat (El-enin and El-feky, 2013).HPMC merupakan salah satu gelling agent yang dapat digunakan dalam sediaan rektal. Berdasarkan penelitian sebelumnya Tween 80 dengan konsentrasi $2,5 \%$ dan $5 \%$ dapat meningkatkan jumlah obat terlepas ketoprofen lebih besar dalam gel transdermal dengan polimer methyl cellulose $5 \%$ bila dibandingkan dengan menggunakan surfaktan asam oleat (Samy et al., 2013). Sedangkan Tween 80 dengan konsentrasi $1 \%, 5 \%$, dan $10 \%$ dapat meningkatkan jumlah obat terlepas natrium diklofenak lebih besar dalam basis gel natrium metilselulosa dibandingkan menggunakan surfaktan dimetilsulfoksida
(Novita, 2011). Berdasarkan latar belakang di atas perlu dilakukan penelitianmengenai pengaruh perbedaan konsentrasi surfaktan Tween 80 sebesar $1 \%, 2,5 \%, 5 \%$ dan $7,5 \%$ terhadap sifat mutu fisik dan laju pelepasan gel rektal ketoprofen dengan basis gel HPMC sebesar $3 \%$.

\section{METODE PENELITIAN} Alat

Alat yang digunakan dalam penelitian ini antara lain Spektrofotometer UV-Vis Single Beam (Hitachi tipe u-1900, Jepang), Franz Diffusion Cell yang dimodifikasi (Departemen Teknik Fisika-Institut Teknologi Bandung), Stirer, Viskometer Brookfield, $\mathrm{pH}$ meter, timbangan analitik, peralatan gelas, dan alat pendukung lainnya.

\section{Bahan}

Bahan yang digunakan dalam penelitian ini antara lain ketoprofen (diperoleh dari PT. Interbat), HPMC, Tween 80, gliserin, metil paraben, propil paraben, membran Whatman $0,45 \mu \mathrm{m}$ (PT. Indofa), dan bahan kimia lainnya.

\section{Pembuatan gel rektal ketoprofen}

Bahan formula gel disiapkan seperti yang tertera pada tabel 1, metil paraben dan propil paraben dilarutkan dalam air panas dan ditambahkan gliserin. Campuran tersebut ditambahkan ke dalam gel HPMC yang telah mengembang sempurna. Gel HPMC dibuat dengan cara ditaburkan dalam $2 / 3$ bagian air panas dan $1 / 3$ bagian air dingin sebanyak 20 kali bobot HPMC kemudian didiamkan selama 24 jam. Ketoprofen yang telah terbasahi Tween 80 ditambahkan ke dalam campuran tersebut dan digerus hingga membentuk massa gel yang homogen.

\section{Evaluasi mutu fisik gel rektal}

TABEL 1. Formula Gel Rektal .

\begin{tabular}{lccccc}
\hline \multirow{2}{*}{ Bahan } & \multicolumn{5}{c}{ Konsentrasi 3 ahan dalam Formula (\%) } \\
\cline { 2 - 6 } & F1 & F2 & F3 & F4 & F5 \\
\hline Ketoprofen & 2 & 2 & 2 & 2 & 2 \\
HPMC & 3 & 3 & 3 & 3 & 3 \\
Tween 8 o & 1 & 2,5 & 5 & 7,5 & - \\
Nipagin & 0,075 & 0,075 & 0,075 & 0,075 & 0,075 \\
Nipasol & 0,02 & 0,02 & 0,02 & 0,025 & 0,02 \\
& 5 & 5 & 5 & & 5 \\
Gliserin & 20 & 20 & 20 & 20 & 20 \\
Aquadest & ad & ad & ad & ad & ad \\
& 100 & 100 & 100 & 100 & 100 \\
\hline
\end{tabular}

Evaluasi mutu fisik gel rektal yang dilakukan meliputi uji organoleptis dengan melakukan pengamatan secara langsung warna, bentuk dan bau dari sediaan. Uji homogenitas dilakukan dengan mengamati ada tidaknya butiran kasar pada sediaan. Uji daya sebar 
dilakukan dengan cara mengamati diamater penyebaran gel setelah diberi pemberat sejumah 125 gram dan didiamkan selama 1 menit, tujuannya untuk mengetahui kemampuan menyebar gel ketika digunakan. Uji viskositas dilakukan dengan menggunakan alat viscometer brookfield dengan meletakkan sejumlah $100 \mathrm{ml}$ sediaan dalam beaker glass dan dilakukan pengaturan kecepatan serta ukuran spindel. Uji pH sediaan dilakukan dengan menggunakan alat pH meter yang telah dikalibrasi dengan dapar standar $\mathrm{pH} 4$ dan $\mathrm{pH}$ 7, kemudian elektroda dicelupkan ke dalam sediaan sehingga nilai $\mathrm{pH}$ sediaan akan tertera pada layar.

\section{Validasi metode penetapan kadar gel rektal}

Penetapan panjang gelombang

Panjang gelombang maksimum ditentukan dengan cara larutan baku pada konsentrasi tengah (9 $\mu \mathrm{g} / \mathrm{mL}$ ) diamati dengan spektrofotometer UVVis pada panjang gelombang dengan rentang 200$400 \mathrm{~nm}$ dalam pelarut dapar fosfat $\mathrm{pH} 7,4$. Ketoprofen memberikan serapan maksimum pada panjang gelombang $260 \mathrm{~nm}$.

\section{Linieritas}

Pembuatan larutan baku induk dengan cara ketoprofen sebanyak $25 \mathrm{mg}$ dilarutkan dengan dapar fosfat $\mathrm{pH} 7,4$ dalam labu takar $100 \mathrm{ml}$ sehingga diperoleh konsentrasi $250 \mu \mathrm{g} / \mathrm{ml}$. Dari larutan baku induk dilakukan pengenceran menjadi 8 konsentrasi yang berbeda yaitu $1 ; 3 ; 5$; $7 ; 9 ; 11 ; 13 ; 15 \mu \mathrm{g} / \mathrm{ml}$.

\section{Akurasi dan Presisi}

Uji akurasi untuk penetapan kadar ketoprofen menggunakan 3 tingkat konsentrasi yaitu $80 \%$, 100\%, dan 120\%. Sejumlah bahan aktif pada konsentrasi tersebut ditambahkan dengan matriks gel kemudian dilarutkan dalam dapar fosfat $\mathrm{pH} 7,4$ dan dilakukan pengenceran hingga diperoleh rentang konsentrasi 7; 9; $11 \mu \mathrm{g} / \mathrm{ml}$. Uji presisi penetapan kadar ketoprofen menggunakan konsentrasi 100\%.

\section{Penetapan kadar ketoprofen dalam gel rektal}

Sampel gel rektal sebanyak $500 \mathrm{mg}$ yang setara dengan $10 \mathrm{mg}$ ketoprofen dilarutkan dengan dapar fosfat $\mathrm{pH} 7,4$ dalam labu takar 100 $\mathrm{ml}$. Kemudian dilakukan pengenceran sehingga diperoleh konsentrasi $9 \mu \mathrm{g} / \mathrm{ml}$.

\section{Uji pelepasan secara In vitro}

Uji pelepsan secara in vitro menggunakan alat Franz diffusion celldengan luas area $3,14 \mathrm{~cm}^{2}$ dan volume kompartemen reseptor $30 \mathrm{ml}$ yang berisi dapar fosfat $\mathrm{pH}$ 7,4. Masing-masing formula gel ditimbang sebanyak 3 gram diletakkan pada kompartemen donor dan membran whatman $0,45 \mu \mathrm{m}$ digunakan sebagai pemisah antar kompartemen. Pengambilan cuplikan sampel sebanyak 2 ml dilakukan pada menit ke 15; 30; 45;
60; 90; 120 menit. Penentuan kadar sampel ditentukan dengan spektrofotometer UV-VIS.

\section{HASIL DAN PEMBAHASAN \\ Evaluasi mutu fisik gel rektal}

Hasil uji organoleptis terhadap masingmasing sediaan tidak terdapat perbedaan secara penampilan fisik yaitu seluruh sediaan berbentuk gel, berwarna putih dan tidak berbau.Hasil evaluasi homogenitas terhadap masing-masing formula gel rektal ketoprofen menunjukkan hasil bahwa seluruh formula tidak memisah dan tidak terdapat butiran kasar sehingga dapat digolongkan dalam kategori homogen. F1,F2,F3,F4 yang mengandung Tween 8o memiliki daya sebar yang lebih baik dibandingkan F5 yang tidak mengandung Tween 80 , hasil dapat dilihat pada tabel 2.

TABEL 2. Hasil uji daya sebar.

\begin{tabular}{ccccc}
\hline \multirow{2}{*}{ Formula } & \multicolumn{3}{c}{$\begin{array}{c}\text { Diameter Daya Sebar } \\
\text { (cm) }\end{array}$} & $\begin{array}{c}\text { Rata- } \\
\text { rata } \pm \text { SD }\end{array}$ \\
\cline { 2 - 4 } & $\begin{array}{c}\text { Batch } \\
\text { 1 }\end{array}$ & $\begin{array}{c}\text { Batch } \\
\mathbf{2}\end{array}$ & $\begin{array}{c}\text { Batch } \\
\mathbf{3}\end{array}$ & \\
\hline F1 & 5,13 & 5,30 & 5,20 & $5,21 \pm 0,08$ \\
F2 & 6,17 & 6,23 & 6,20 & $6,20 \pm 0,03$ \\
F3 & 6,40 & 6,50 & 6,46 & $6,45 \pm 0,05$ \\
F4 & 6,73 & 6,70 & 6,76 & $6,73 \pm 0,03$ \\
F5 & 4,67 & 4,70 & 4,73 & $4,70 \pm 0,03$ \\
\hline
\end{tabular}

Nilai viskositas yang dihasilkan dari sediaan yaitu $6630-7740$ cps, hasil uji viskositas yang diperoleh diluar rentang spesifikasi yang ditentukan yaitu gel rektal yang baik memiliki viskositas 1000-2000 cps (Dabbagh, Ameri, and Honarmand, 2007) hal ini dikarenakan adanya bahan lain dalam formula yang dapat mempengaruhi viskositas sediaan yaitu gliserin. Semakin besar konsentrasi Tween 80 yang ditambahkan dapat menurunkan viskositas sediaan,hasil dapat dilihat pada tabel 3. Nilai $\mathrm{pH}$ sediaan berada dalam rentang 5,4-5,6 dimana nilai $\mathrm{pH}$ tersebut masih sesuai untuk menghindari resiko iritasi ketika digunakan dan $\mathrm{pH}$ diterima sekitar 5,5 (Ambala and Vemula, 2015).

TABEL 3. Hasil Uji Viskositas.

\begin{tabular}{cccccc}
\hline \multirow{2}{*}{ Batch } & \multicolumn{5}{c}{ Viskositas (Cps) } \\
\cline { 2 - 6 } & F1 & F2 & F3 & F4 & F5 \\
\hline 1 & 7630 & 7460 & 6950 & 6670 & 7720 \\
2 & 7650 & 7450 & 6940 & 6650 & 7720 \\
3 & 7620 & 7440 & 6930 & 6670 & 7730 \\
Rerata & 7633,3 & 7450,0 & 6940,0 & 6663,3 & 7723,3 \\
\pm SD & $\pm 15,27$ & $\pm 10,00$ & $\pm 10,00$ & $\pm 11,54$ & $\pm 5,77$ \\
\hline
\end{tabular}

\section{Uji pelepasan secara in vitro}

Secara kualitatif fluks pelepasan ketoprofen dalam sediaan gel rektal dari yang tertinggi sampai terendah berturut-turut dihasilkan oleh F4, F3, F2, F1 dan F5. Pada formula yang mengandung Tween 80 memiliki nilai fluks pelepasan yang lebih besar dibandingkan formula 
yang tidak mengandung Tween 80 yaitu pada $\mathrm{F}_{5}$, perbedaan nilai fluks dapat dilihat pada tabel 4 .

TABEL 4. Hasil Uji Pelepasan Gel Rektal Ketoprofen.

\begin{tabular}{cccccc}
\hline \multirow{2}{*}{ T (h) } & \multicolumn{5}{c}{ Q rata-rata $\left(\boldsymbol{\mu g} / \mathbf{c m}^{\mathbf{2}} \pm \mathbf{S D}\right)$} \\
\cline { 2 - 6 } 0,25 & $\mathbf{F 1}$ & F2 & $\mathbf{F 3}$ & $\mathbf{F 4}$ & F5 \\
\hline \multirow{2}{*}{0,25} & $\mathbf{3}, 2$ & 89,2 & 120,5 & 130,6 & 76,1 \\
& $\pm 3,6$ & $\pm 1,0$ & $\pm 2,4$ & $\pm 1,5$ & $\pm 3,4$ \\
0,5 & 92,5 & 97,3 & 140,6 & 175,3 & 81,9 \\
& $\pm 1,2$ & $\pm 0,7$ & $\pm 4,1$ & $\pm 1,4$ & $\pm 2,4$ \\
0,75 & 97,1 & 117,7 & 164,7 & 380,6 & 86,6 \\
& $\pm 2,5$ & $\pm 2,2$ & $\pm 12,8$ & $\pm 4,5$ & $\pm 0,6$ \\
1 & 119,0 & 131,8 & 212,9 & 516,6 & 99,2 \\
& $\pm 3,0$ & $\pm 4,6$ & $\pm 13,1$ & $\pm 1,9$ & $\pm 1,7$ \\
1,5 & 133,6 & 153,0 & 315,3 & 607,8 & 109,4 \\
& $\pm 3,4$ & $\pm 2,0$ & $\pm 14,4$ & $\pm 5,0$ & $\pm 1,7$ \\
2 & 198,9 & 245,7 & 561,6 & 663,2 & 131,7 \\
& $\pm 2,8$ & $\pm 9,6$ & $\pm 10,4$ & $\pm 19,8$ & $\pm 1,9$ \\
\hline
\end{tabular}

Tween 80 merupakan surfaktan nonionik yang dapat meningkatkan kelarutan obat yang bersifat lipofil atau sukar larut dalam air dengan cara menurunkan tegangan antar muka ketoprofen dengan medium. Jumlah obat terlepas pada formula yang tidak mengandung Tween 80 yaitu $\mathrm{F}_{5}$ bernilai lebih kecil karena tidak terdapat bahan yang dapat membantu kelarutan dari ketoprofen. Semakin besar konsentrasi Tween 80 menyebabkan fluks pelepasan semakin besar dan pada konsentrasi Tween 80 terbesar yaitu 7,5\% dalam formula tidak menyebabkan terbentuknya misel yang dapat menghalangi obat terlepas. Profil pelepasan yang dihasilkan menunjukkan bahwa Tween 80 tidak hanya membantu meningkatkan kelarutan obat tetapi juga meningkatkan kecepatan pelepasan obat. Kecepatan pelepasan obat dipengaruhi oleh penurunan viskositas sediaan akibat adanya penambahan surfaktan. Jumlah obat terlepas ketoprofen dan kecepatan pelepasan akan mempengaruhi bioavailabilitas obat dalam tubuh karena menentukan jumlah obat yang diabsorbsi.

Ketoprofen memiliki permeabilitas yang tinggi dan yang menjadi faktor penentu adalah kelarutan dan kecepatan pelepasan sehingga jumlah obat terlepas seluruhnya akan diabsorbsi karena biovailabilitas obat dapat menentukan efek

\section{DAFTAR PUSTAKA}

Allen, L.V., 2009. Compounding Rectal Dosage Forms, Part I, Current and Practical Compounding Information for the Pharmacist, 14(2): 1-6.

Ambala, R., Vemula, S.K., 2015. Formulation and Characterization of Ketoprofen Emulgels, Journal of Applied Pharmaceutical Science, 5(7): 112-117

Dabbagh, M.A., Ameri, A., Honarmand, M., 2007. Preparation of Diazepam Rectal Gel Using Cellulose Polymers. Jundishapur Journal of Natural Pharmaceutical Products. 2(1) 34-44.

Depkes R.I., 2008. Daftar Obat Esensial Nasional. Jakarta: Direktorat Jendral Bina Kefarmasian dan Alat Kesehatan. 16.

El-enin, A.S.M.A., and El-feky, G.S., 2013. Formulation and Evaluation of In-situ Gelling Tenoxicam Liquid Suppositories, farmakologi (Shargel and $\mathrm{Yu}, 2005$ ). Hasil uji pelepasan dan profil pelepasan dapat dilihat pada tabel 4 dan gambar 1.

TABEL 5. Persamaan Linier Antara $\sqrt{t}$ versus Jumlah Obat Terlepas.

\begin{tabular}{ccc}
\hline Formula & Persamaan & $\begin{array}{c}\text { Fluks Pelepasan } \\
\text { (Fluks } \\
\left(\boldsymbol{\mu g} / \mathbf{c m}^{2} / \mathbf{j a m} \mathbf{j} \mathbf{2}\right)\end{array}$ \\
\hline F1 & $\mathrm{y}=111,66 \mathrm{x}+15,407$ & 111,660 \\
F2 & $\mathrm{y}=155,47 \mathrm{x}-8,885$ & 155,465 \\
F3 & $\mathrm{y}=449,65 \mathrm{x}-175,471$ & 449,648 \\
F4 & $\mathrm{y}=644,85 \mathrm{x}-201,569$ & 644,853 \\
F5 & $\mathrm{y}=59,72 \mathrm{x}+40,620$ & 59,722 \\
\hline
\end{tabular}

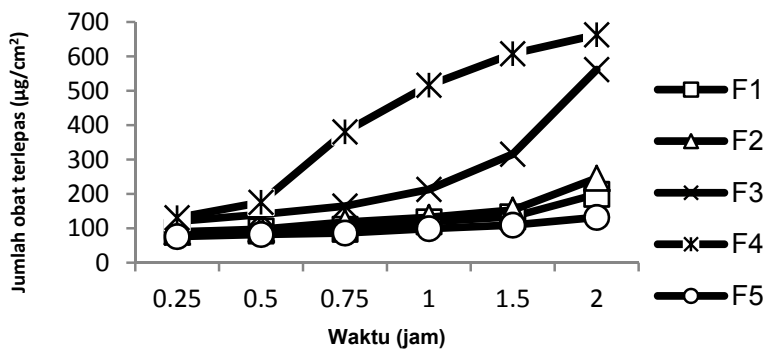

GAMBAR 1. Profil Pelepasan Gel Rektal Ketoprofen

\section{KESIMPULAN}

Tween 80 dengan konsentrasi berbeda tiap formula dapat mempengaruhi sifat mutu fisik gel rektal yaitu viskositas dan daya sebar. Formula yang mengandung Tween 80 yaitu F1, F2, F3, dan F4 memiliki viskositas yang lebih rendah dan lebih mudah menyebar dibandingkan formula yang tidak mengandung Tween 80 yaitu $\mathrm{F}_{5}$. Semakin besar konsentrasi Tween 80 menyebabkan viskositas semakin rendah dan lebih mudah menyebar.Penambahan Tween 80 dapat mempengaruhi laju pelepasan gel rektal ketoprofen. Formula yang mengandung Tween 80 yaitu F1, F2, F3, dan F4 memiliki fluks pelepasan lebih besar dibandingkan Formula yang tidak mengandung Tween 80 yaitu F5. Semakin besar konsentrasi Tween 80 menyebabkan fluks pelepasan semakin besar.
Journal of Life Medicine. 1(2). 23-32.

Hosny, K.M., Rambo, S.M., Al-Zahrani, M.M., Al-Subhi, S.M., Fahmy, U.A., 2013. Ketoprofen Emulgel Preparation, Characterization, and Pharmacodynamic Evaluation, International Journal Pharmaceutical Science. Jeddah. 20(2). 306-310.

Novita, F.G., 2011. Pengaruh Tween 80 dan Dimetilsulfoksida Terhadap Penetrasi Gel Natrium Diklofenak Menggunakan Spektrofotometer UV-VIS, Jurnal Farmasi Sains. Riau. 1(3). 139-142.

Rencber, S., Karavana, S.Y., and Ozyazici, M., 2009. Bioavaibility File: Ketoprofen, Journal Pharmaceutical Science. Bornova, Izmir. 34. 203-216. 
Samy, A.M., Ghorab, M.M., Shadeed, S.G., Mazyed, E.A., 2013. Design, Formulation and Evaluation of Transdermal Ketoprofen Gel, Journal of American Science. Nasr. 9(3). 273-242.

Shargel, L., dan Yu, Andrew, B.C. 2005. Biofarmasetika dan Farmakokinetika Terapan. Edisi kedua. Penerjemah: Dr. Fasich,
Apt. dan Dra. Siti Sjamsiah, Apt. Surabaya: Airlangga University Press.

Yadav, P.S., Kondawar, M.S., Varne, B.S., 2013. Enhancement of dissolution Properties of candesartan Using Liquidsolid Technique, International Journal of Advances in Pharmaceutical Researh. 4(2). 2503-2513. 